Infirmary; or Drs. Marshall Hall, Hope, Sims, A. T. Thomson, \&c., who have either actually held, or competed for, and thus shown their anxiety to hold gratuitous office at that institution. Surely, if gentlemen of their age and position will do this, it is very unjust to saddle the younger members of our profession with the blame for the existing state of things. I am, sir,

January 18, 1845.

Your constant reader,

Veritas.

** The elders of the profession have set many examples which the younger should not follow, and have often endeavoured to establish precedents which ought not to be respected by their juniors. How can a vicious course of conduct ever be expected to cease if such an apology for its continuance be permitted as that urged by "VeRITAS"?

\section{TERM OF PREGNANCY.}

To the Editor of THE LANCET.

SIR,-The insertion of the subjoined statement of facts, relative to the term of human pregnancy, in your valuable journal, will oblige me:-

IIrs. $M-$, the mother of one child, applied to me in the month of August last, to engage my attendance in an approaching accouchement. Upon asking her at what period she expected to be confined, she replied on the 13th of December; and for fixing the day so precisely, she gave the following reason-viz., that her husband was a butler in a gentleman's family, residing in the country, consequently compelled to live apart from her; bot that on the 13th of March he came to London and stayed with her on that night only, being obliged to return to his master's residence the next day. Now for the result:- She had calculated nine calendar months as the duration of human pregnancy, and consequently had fixed the 13 th of December as the day of delivery. I, however, in my own mind, had fixed the 18 th as the day on which gestation was to be completed-i. e, forty weeks after coitus. She was not, however, delivered on the 18th, but labour commenced at six o'clock P.M., on the 20th, and terminated in the birth of a full-grown child, a fow minutes before twelve, forty-eight hours only after the time I had anticipated. J. J. TwEed, Jun., M.R.C.L.S.

Gilbert-street, Grosvenor-square. January 17,1845 .

\section{REMARKS OF MR. HILLES AT THE MEDICAI PROTECTION ASSEMBLY.}

To the Editor.-Sir, I shall feel obliged by your correcting the report which appeared in THE LaNCET of the 25 th inst., of the observations made by me on the preceding Monday, (20th inst., at a meeting of the Medical Protection Assembly at Exeter Hall. I am reported to have said, that " the object was not to throw obloquy, or indulge in severe invective, on any minister of state, as some associations had done." Now, I did not accuse any association of having acted in this manner. However anxions I am, and always have been, to promote the cause of medical reform, and advance the interests of the Medical Protection Assembly, have studiously aroided any attempt to accomplish either of these objects by bringing forward accusations against either individuals or associations, engaged in the same cause with me, unless in the most public manner, and when they had the opportunity of replying to such, if they considered it necessary, and have always aeted on this principle. Again, I am represented as saying, "that I would join the body that would carry out the representative principle." This is also incorrect, as I distinctly stated I could not join the Association of General Practitioners, as $I$ am not in general practice, although I would recommend my professional brethren (general practitioners) to do so if that body would recognise the principle of representation.

$$
\text { I am, sir, most respectfully yours, }
$$

Pímlico, 27 Jan. 1845.

$$
\text { M. W. Hrries. }
$$

\section{ON THE PROPRIETY OF DIVIDING ADHESIONS IN THE OPERATION FOR HERNIA. (A QUERY.) \\ To the Editor of TrE LANCET.}

Sir,-At the desire of very many unprofessional persons, forming a large portion of the inhabitants of this town, $I$ am requested to solicit the favour of the authority of your decision on the following question:-

At a post-mortem examination, after the fatal issue of an operation for hernia, where death supervened, with permanent consti- pation, on the fifth day after the operation, the following state of parts was discovered:-

"About two inches of discoloured intestine was lying in contact with the internal ring, and adhering to it. Considerable bands confined the bowel to the sac. These bands confined the bowel so as to form a kind of knuckle at rather an acute angle.

"The small, discoloured portion of intestine was doubled back on itself, and had been permanently kept in that position by transverse bands of long standing.

"The knuckle of the gut formed an angle, and the serous surfaces thus placed in apposition were firmly adherent."

Query - What is the consequence of returning the intestine in such a state of preternatural adhesion?

By affording the "authority" of your decision upon the foregoing question, you will greatly oblige many of your far distant but constant readers.

Your obedient servant,

B. RAYGARTH, M.D. \&c. (Formerly student at Guy's.)

Launceston, Van Dieman's Land, May 6, 1844.

** Not having before us the detailed history of the case alluded to by our correspondent, and not knowing for what purpose our opinion is demanded on a point which, in reality, admits of but little, if any discussion, we must remind our professional readers in Van Dieman's Land that we merely take upon us to answer the above surgical query as it is put to us; not to give an opinion respecting the merits or demerits of the treatment pursued in the particular case referred to.

It is a rule in operating for hernia, to break down or to destroy any adhesions which may exist between the intestine and the sac, or be ran the folds of the intestine themselves. Indeed, it is partly with a view to ascertain whether any such adhesions exist beyond the stricture, that many surgeons recommend a small portion of intestine to be gently drawn out after the division of the stricture, previous to returning the contents of the sac into the carity of the abdomen. The probable consequence of returning folds of intestine which are united to each other at an acute angle by false membranes, is the persistence of the symptoms of strangulation. No practical surgeon could intentionally commit such an error. The existence of adhesions may, however, escape the notice of the operator, or they may be situated so high as not to be discernible. When this occurs, the termination of the case is generally fatal. If the intestine really was returned in the state described by Dr. Raygarth, and the adhesions were not the result of subsequent inflammation, an error was certainly committed. M. Maisonneuve has recently presented to the Academy of Sciences, Paris, the details of a case in which, having operated on an old lady for inguinal hernia, without giving relief, owing to the presence, as he afterwards found, of internal adhesions, he re-opened the wound, and not being able to destroy the adhesions, established an artificial anus.-ED. I.

\section{NEWS OF THE WEEK.}

The Inventions respecting the College of Surgeons op ENGLAND.- We have authority to state that there is no sort of foundation for statements put forward in the Times newspaper with respect to certain changes said to be contemplated in the constitution of the College of Surgeons of England. These statements were copied from an obscure medical periodical, for which, we understand, they were fabricated, with a full knowledge of their incorrectness.-Dublin Medical Press, Jan. 29.

Porsoning from Arsentc used in Compostte Candles.The use of so deadly a poison as arsenic in the manufacture of candles cannot be too severely condemned, because it is only employed with a view to stain tallow candles, and to give them a nearer resemblance to wax. In France and Belgium, the Government has interfered, and forbidden the practice entirely, under a heary penalty, after a full investigation of the subject. As these composite candles burn, the arsenic is imperceptibly volatilized, and its vapours may have a prejudicial effect on the health of those who are exposed to them. We want the assistance of a properly organized practical Council. We suppose it is idle to advise the public to avoid using these composite candles, until some precautionary regulation is adopted with reference to their manufacture.

On Friday, Jan. 3rd, an inquest was held by one of the deputy coroners for Middlesex, at the Kenilworth Castle, Islington, on the body of Joseph Haggett, aged twenty-one, late a workman of Messrs. Le Paige and Co., compasite candle manufacturers, Great Suffolk-street, Borough. 